\title{
Design of a new lyoprotectant increasing freeze-dried Lactobacillus strain survival to long-term storage
}

Aurore Bodzen ${ }^{1,2}$, Audrey Jossier ${ }^{1}$, Sébastien Dupont ${ }^{1}$, Pierre-Yves Mousset ${ }^{2}$, Laurent Beney ${ }^{1}$, Sophie Lafay ${ }^{2}$ and Patrick Gervais ${ }^{1 *}$

\begin{abstract}
Background: Stabilization of freeze-dried lactic acid bacteria during long-term storage is challenging for the food industry. Water activity of the lyophilizates is clearly related to the water availability and maintaining a low $\mathrm{a}_{\mathrm{w}}$ during storage allows to increase bacteria viability. The aim of this study was to achieve a low water activity after freezedrying and subsequently during long-term storage through the design of a lyoprotectant. Indeed, for the same water content as sucrose (commonly used lyoprotectant), water activity is lower for some components such as whey, micellar casein or inulin. We hypothesized that the addition of these components in a lyoprotectant, with a higher bound water content than sucrose would improve lactobacilli strains survival to long-term storage. Therefore, in this study, $5 \%$ whey $(\mathrm{w} / \mathrm{v}), 5 \%$ micellar casein $(\mathrm{w} / \mathrm{v})$ or $5 \%$ inulin $(\mathrm{w} / \mathrm{v})$ were added to a $5 \%$ sucrose solution $(\mathrm{w} / \mathrm{v})$ and compared with a lyoprotectant only composed of $5 \%$ sucrose $(\mathrm{w} / \mathrm{v})$. Protective effect of the four lyoprotectants was assessed measuring Lactiplantibacillus plantarum CNCM I-4459 survival and water activity after freeze-drying and during 9 months storage at $25^{\circ} \mathrm{C}$.
\end{abstract}

Results: The addition whey and inulin were not effective in increasing Lactiplantibacillus plantarum CNCM I-4459 survival to long-term-storage (4 log reduction at 9 months storage). However, the addition of micellar casein to sucrose increased drastically the protective effect of the lyoprotectant (3.6 log i.e. 0.4 log reduction at 9 months storage). Comparing to a lyoprotectant containing whey or inulin, a lyoprotectant containing micellar casein resulted in a lower water activity after freeze-drying and its maintenance during storage $(0.13 \pm 0.05)$.

Conclusions: The addition of micellar casein to a sucrose solution, contrary to the addition of whey and inulin, resulted in a higher bacterial viability to long-term storage. Indeed, for the same water content as the others lyoprotectants, a significant lower water activity was obtained with micellar casein during storage. Probably due to high bound water content of micellar casein, less water could be available for chemical degradation reactions, responsible for bacterial damages during long-term storage. Therefore, the addition of this component to a sucrose solution could be an effective strategy for dried bacteria stabilization during long-term storage.

Keywords: Lactiplantibacillus, Long-term storage, Water activity, Bound water, Lyoprotectant, Freeze-drying, Micellar casein

*Correspondence: patrick.gervais@u-bourgogne.fr

1 UMR Procédés Alimentaires et Microbiologiques, University Bourgogne Franche-Comté, AgroSup Dijon, PAM UMR A 02.102, 21000 Dijon, France Full list of author information is available at the end of the article

\section{Background}

Preservation of lactic acid bacteria (LAB) by freeze-drying is commonly used for long-term storage of functional food supplements and starters [1]. Freeze-drying removes 
intracellular water from bacteria until a low water activity $\left(a_{w}\right)$ level $\left(a_{w} \leq 0.2\right)$ is reached, which results in the reduction or abortion of cell metabolic activities [2]. Freeze-drying process is made up of three steps: freezing which is the main critical step for maintaining bacterial viability during freeze-drying, sublimation (first drying step) and a secondary drying step. During freezing, ice first forms in the extracellular medium due to a higher solute concentration in cells than in the extracellular medium. Extracellular ice formation increases extracellular solute concentration resulting in an osmotic gradient between the cell and the extracellular medium [3]. This difference in osmotic pressure causes water outflow of the cell and cell dehydration. Cells damages occur during the freezing step depend on the kinetic of cooling. For rapid cooling rates, water is retained within the cells, leading to the formation of intracellular ice and cell damage $[4,5]$. Moreover, the increase of cell surface/volume ratio resulting from rapid cooling rates causes membrane deformations such as shrinkage and vesiculation $[6,7]$. Vesiculation induces membrane surface depletion and then permeabilization during rehydration because of the lack of membrane surface [8]. If a slow cooling rate is used, cellular damages are caused by hyperosmotic stress and severe dehydration [9]. Dehydration results in high solute concentration in the extracellular medium ("cryoconcentration") and therefore in high osmotic stress. Cryoconcentration during freezing creates irreversible damages to the macromolecules, particularly proteins of cell surface, acting directly on bacteria viability [10]. Then, during the second step of freeze-drying (sublimation), pressure reduction in the freeze-drier causes the sublimation of the frozen water of the bacterial formulation [11]. The product temperature has to be maintained below the glass transition temperature of the protectant $\left(\mathrm{T}_{\mathrm{g}}\right)$ to remain in the amorphous glassy state throughout freeze-drying and storage and to prevent the collapse of the matrix structure [12]. Moreover, sublimation must be completed before the product temperature reaches the melting point of ice $\left(0{ }^{\circ} \mathrm{C}\right)$. Therefore shelf temperature rise must be controlled to avoid product collapse or melting [13]. Following sublimation, bound water of the product is removed during a secondary drying step, which includes a slight rise in temperature. During this step, the product temperature also has to be maintained below the $\mathrm{T}_{\mathrm{g}}$ of the protectant. The secondary drying is completed when low $\mathrm{a}_{\mathrm{w}}$ values of the product are reached (usually below 0.2).

Regulations on functional food supplements impose their stability (i.e. survival of bacteria) for two years of storage usually at $25^{\circ} \mathrm{C}$. Bacterial damages due to freezedrying (especially due to the freezing step) result in bacterial death during rehydration, highlighting the need of suitable storage conditions. Storage conditions such as $a_{w}$, temperature, presence of light and gaseous atmosphere, are key factors in the loss of viability and generally more than $1 \log$ of loss is observed for probiotics preparation over one month of storage at $25^{\circ} \mathrm{C}$ [14]. Cell damages mechanisms are as diverse as protein aggregation, lipid oxidation or Maillard reaction of reducing sugars [13]. Most used protection strategies to prevent freezedrying and storage cell death are the control of the cooling rate, the addition of lyoprotectants and the control of storage conditions.

Although freezing is the first step of freeze-drying, there is a large difference between cryoprotectants and lyoprotectants. Cryoprotectants are only used when bacteria are stored in frozen form. Glycerol, the most widely used cryoprotectant, is not recommended as a lyoprotectant. Indeed, the percentage of unfrozen water in glycerol is very high (about 45\%) [15], thus increasing the duration of the secondary drying and the costs of freezedrying. In addition, because pure glycerol is liquidous at storage temperature and the $\mathrm{T}_{\mathrm{g}}$ of anhydrous glycerol is very low $\left(-93^{\circ} \mathrm{C}\right)[16]$, maintaining the system temperature below the $T_{g}$ during freeze-drying and storage is not possible, resulting in matrix collapse. The molecules used as lyoprotectants must therefore meet several criteria and their addition should result in (1) an initial withdrawal of intracellular water before freeze-drying, preventing damages due to freezing, (2) formation of an amorphous glass matrix with an extreme viscosity (vitrification) [17] which protects protein structure and stability [18] and increases cell stability thought freeze-drying and long-term storage [19], (3) an increase of the $T_{g}$ of the formulation, with $\mathrm{T}_{\mathrm{g}}$ as high as possible so that the product temperature is appropriate for freeze-drying and that the product remains in a glassy state during storage despite generally high temperatures $\left(25^{\circ} \mathrm{C}\right)[12,20$, $21]$, iv) hydrogen bonds formation with membrane proteins (water replacement hypothesis), thus preserving the native structure of membrane proteins during the withdrawal of water [22, 23]. Non-reducing disaccharides, such as sucrose are generally used as lyoprotectant.

Numerous studies have shown that maintaining a low relative humidity $(\mathrm{RH})$ of the atmosphere i.e. a low $\mathrm{a}_{\mathrm{w}}$ of the product during storage (dried product equilibrated at different $\mathrm{RH}$ using saturated salt solution before or during storage) increases bacterial stability over long-term storage [21, 24-32]. When the bacteria formulation moisture content increases during storage, the "dormant state" of the bacteria is reverted and cell damages (lipid oxidation, protein denaturation) can occur often resulting in cell death [19]. In addition, a low $\mathrm{a}_{\mathrm{w}}$ during storage could also be obtained using molecules with a high bound water content. Indeed, 
as observed by comparison of sorption isotherms, at similar water content, a lower $\mathrm{a}_{\mathrm{w}}$ is achieved with these components. Among these components, whey, micellar casein or inulin are highly relevant in this context.

Skim milk was widely investigated as a lyoprotectant to maintain bacterial viability during long-term storage [33, 34]. Skim milk is composed of $50 \%(\mathrm{w} / \mathrm{w})$ lactose (reducing disaccharide) and 30\% (w/w) milk proteins (e.g., whey, casein). Comparing sorption isotherms of these milk proteins [35-37] with sucrose [38] leads us to the conclusion that these proteins have a higher bound water content than sucrose (micellar casein $>$ whey $>$ sucrose). Whey and micellar casein can also increase the $\mathrm{T}_{\mathrm{g}}$ of a formulation due to their very high $\mathrm{T}_{\mathrm{g}}\left(\mathrm{T}_{\mathrm{g}}\right.$ anhydrous whey: $127{ }^{\circ} \mathrm{C} ; \mathrm{T}_{\mathrm{g}}$ anhydrous casein: $\left.132{ }^{\circ} \mathrm{C}\right)$ compared to sucrose $\left(\mathrm{T}_{\mathrm{g}}\right.$ anhydrous sucrose: $77^{\circ} \mathrm{C}$ ) [39]. Fructo-oligosaccharides (FOS), particularly inulin, have also been used to increase LAB survival to long-term storage $[40,41]$. However, these studies did not monitor $\mathrm{a}_{\mathrm{w}}$ during storage [40] or did not use the freeze-drying method to stabilize bacteria [41]. Inulin, a well-recognized prebiotic, is an heterogeneous mixture of oligosaccharides resulting in a high $\mathrm{T}_{\mathrm{g}}\left(126^{\circ} \mathrm{C}\right.$ for DP10) [39] which maintains more easily the glass state during storage than disaccharides. The comparison of inulin sorption isotherm [42, 43] with sucrose 's [39], shows that inulin also has a higher bound water content than sucrose. Moreover, the benefits of the conjoint use in a lyoprotectant of molecules interacting with membrane, such as disaccharides and polysaccharides with high $\mathrm{T}_{\mathrm{g}}$, to prevent bacterial death during freeze-drying and long-term storage have already been reported [44].

In this context, a lyoprotectant composed of sucrose and a component with a high bound water content seemed to be a suitable strategy to protect bacteria from freeze-drying and also long-term storage damages. In this study, we evaluated the effect of a lyoprotectant containing sucrose + whey, sucrose + micellar casein or sucrose + inulin in comparison with a lyoprotectant only composed of sucrose, to increase LAB strains survival to a freeze-drying process and a long-term storage of 9 months at $25{ }^{\circ} \mathrm{C}$. Sucrose, the most used lyoprotectant for lactic acid bacteria, was chosen because it forms an amorphous matrix, hydrogen bonds with the membrane proteins and its addition leads to a first outflow of water from the cells (less water outflow during freezing). whey, micellar casein and inulin were chosen for their similar $\mathrm{T}_{\mathrm{g}}$ but different bound water content (micellar casein $>$ inulin $>$ whey $>$ sucrose).

\section{Results}

Bacterial survival to freeze-drying

The survival rates of the three LAB strains (L. plantarum CNCM I-4459, L. casei DSM 27537 and L. rhamnosus DSM 16605) to freeze-drying process were determined using four different lyoprotectants and are presented in Fig. 1.

No significant difference in survival rates of L. plantarum CNCM I-4459 (Fig. 1a) was observed between the four lyoprotectants $(p>0.05)$ whereas the survival rates

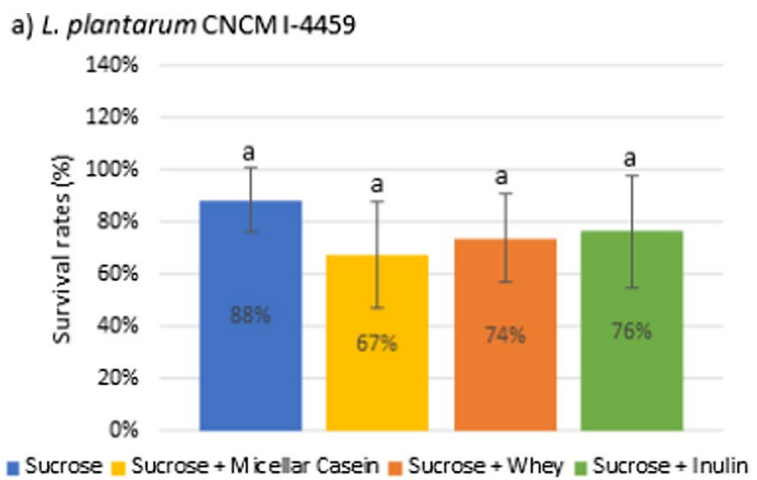

b) L. casei DSM 27537

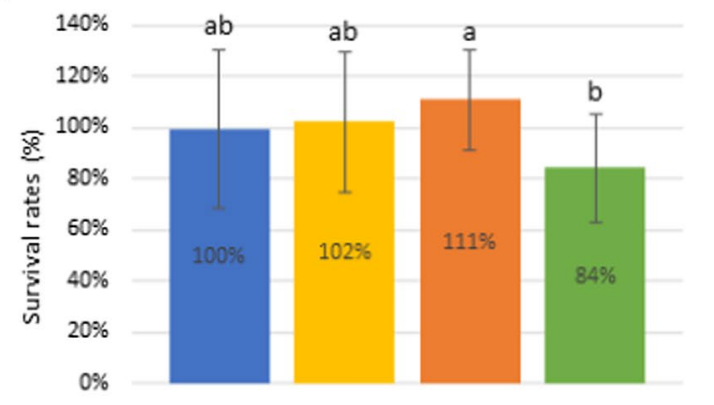

= Sucrose $=$ Sucrose + M cellar Casen $=$ Sucrose + Whey $=$ Sucrose + Inulin

c) L. rhamnosus DSM 16605

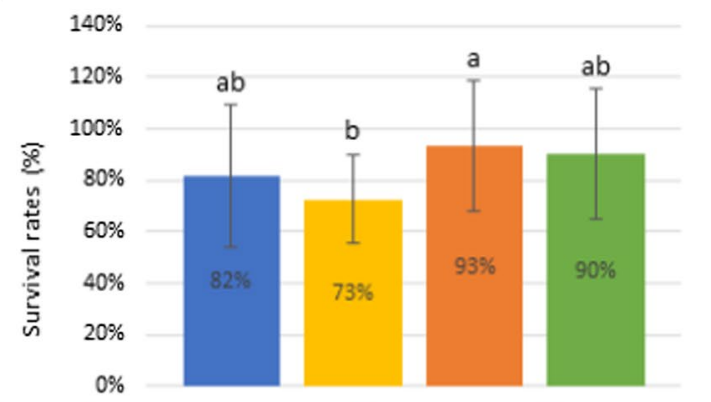

w Sucrose $\|$ Sucrose + M cellar Casen $\|$ Sucrose + Whey $\|$ Sucrose + Inulin

Fig. 1 Survival rates to freeze-drying (\%) of L. plantarum CNCM I-4459 (a), L. casei DSM 27537 (b) et L. rhamnosus DSM 16605 (c) with different lyoprotectants. Values represent mean \pm standard deviation obtained from independent triplicates. Different letters indicate significant differences between lyoprotectants (Tukey's Honest Significant Difference test, $p<0.05$ ) 
of L. casei DSM 27537 (Fig. 1b) and L. rhamnosus DSM 16605 (Fig. 1c) were significantly different. The lyoprotectant containing inulin was the least efficient to protect L. casei DSM 27537 to freeze-drying and the addition of micellar casein or whey did not improve the protection of sucrose. The survival rates of L. rhamnosus DSM 16605 were significantly higher with the lyoprotectant containing whey than with the lyoprotectant containing micellar casein $(p<0.05)$. In addition, L. rhamnosus DSM 16605 survival rates to freeze-drying with the lyoprotectants containing whey and inulin were not significantly different from survival rates with the lyoprotectant containing only sucrose $(p>0.05)$.

A one-sample t-test has also allowed to show that the freeze-drying survival percentages of the three strains with the lyoprotectant containing only sucrose were not significantly different from $100 \%(p>0.05)$.

\section{Bacterial survival to long-term storage}

At each storage time $(0$ month, 0.5 month, 1 month, 3 months and 9 months), L. plantarum CNCM I-4459 cultivable biomass $(\mathrm{CFU} / \mathrm{mL})$ was enumerated. As same as previous results (Fig. 1), there was no significant difference between cultivable bacteria obtained after freezedrying (0) between the four lyoprotectants.

The loss of bacterial cultivability at each storage time and depending on the lyoprotectant, expressed as $\log _{10}$ $\left(\mathrm{N} / \mathrm{N}_{0}\right)$, is presented in Fig. 2.

Bacterial cultivability at each storage time and depending the four lyoprotectants is presented in Table 1.

Firstly, at 15 days, cultivable bacteria were similar between lyoprotectants containing micellar casein, whey and inulin (Table 1), however the loss of cultivability (Fig. 2) was higher for the lyoprotectant containing whey $(0.6 \mathrm{log})$ than with the lyoprotectants containing micellar casein $(0.2 \mathrm{log})$ and inulin $(0.1 \mathrm{log})$. At 1 month, cultivable bacteria obtained with the lyoprotectant containing micellar casein was significantly higher than cultivable bacteria obtained with the lyoprotectants containing whey and inulin (Table 1). The lyoprotectant containing micellar casein was more efficient to protect bacterial survival ( $0.1 \mathrm{log}$ reduction) than the lyoprotectants containing whey (1.4 log reduction) or inulin (1 log reduction) (Fig. 2). Moreover, cultivable bacteria

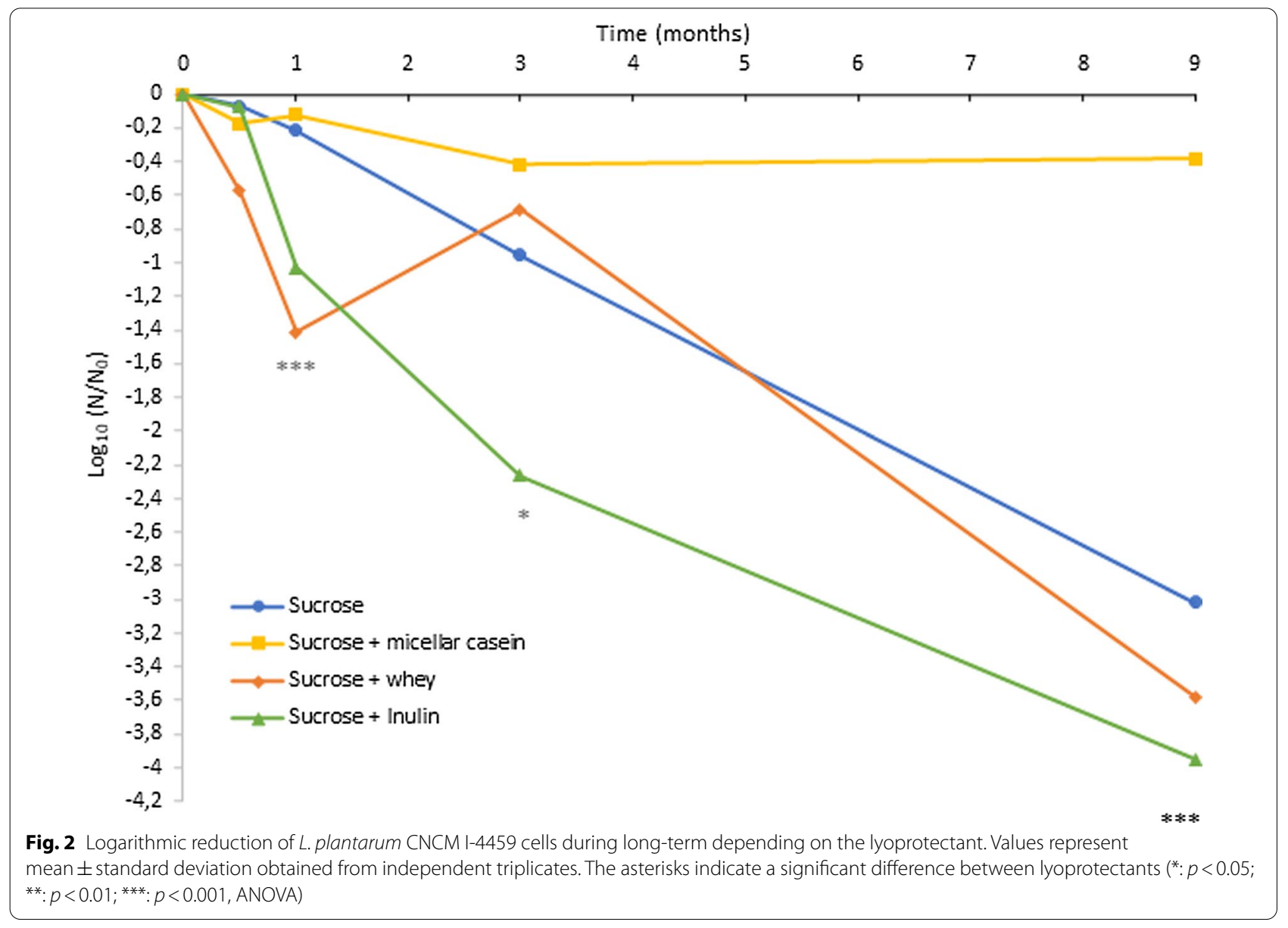


Table 1 Cultivable biomass of L. plantarum CNCM I-4459 (CFU/mL) for each storage time depending on the lyoprotectant

\begin{tabular}{|c|c|c|c|c|c|c|c|c|}
\hline \multirow[t]{2}{*}{ Storage time } & \multicolumn{8}{|c|}{ Lyoprotectants } \\
\hline & Sucrose & & Sucrose + Mic & Casein & Sucrose $+W$ & & Sucrose + Inuli & \\
\hline \multirow[t]{2}{*}{0 month } & $1.9 \times 10^{10}$ & a & $1.4 \times 10^{10}$ & a & $1.8 \times 10^{10}$ & a & $1.8 \times 10^{10}$ & $\mathrm{a}$ \\
\hline & $\pm 2.5 \times 10^{9}$ & & $\pm 1.9 \times 10^{9}$ & & $\pm 1.2 \times 10^{9}$ & & $\pm 1.8 \times 10^{9}$ & \\
\hline \multirow[t]{2}{*}{0.5 month } & $1.6 \times 10^{10}$ & a & $9.4 \times 10^{9}$ & $a b$ & $4.8 \times 10^{9}$ & $b$ & $1.1 \times 10^{10}$ & $a b$ \\
\hline & $\pm 2.0 \times 10^{9}$ & & $\pm 2.1 \times 10^{9}$ & & $\pm 9.7 \times 10^{8}$ & & $\pm 6.6 \times 10^{9}$ & \\
\hline \multirow[t]{2}{*}{1 month } & $1.1 \times 10^{10}$ & $\mathrm{a}$ & $1.0 \times 10^{10}$ & a & $7.9 \times 10^{8}$ & $\mathrm{~b}$ & $1.6 \times 10^{9}$ & $\mathrm{~b}$ \\
\hline & $\pm 4.6 \times 10^{9}$ & & $\pm 2.0 \times 10^{9}$ & & $\pm 7.7 \times 10^{8}$ & & $\pm 6.4 \times 10^{8}$ & \\
\hline \multirow[t]{2}{*}{3 months } & $1.5 \times 10^{9}$ & $a b$ & $3.4 \times 10^{9}$ & a & $2.6 \times 10^{9}$ & $a$ & $1.0 \times 10^{8}$ & $b$ \\
\hline & $\pm 1.0 \times 10^{8}$ & & $\pm 3.0 \times 10^{9}$ & & $\pm 3.6 \times 10^{9}$ & & $\pm 1.4 \times 10^{8}$ & \\
\hline \multirow[t]{2}{*}{9 months } & $1.9 \times 10^{7}$ & $b$ & $5.8 \times 10^{9}$ & a & $4.7 \times 10^{6}$ & $b$ & $1.9 \times 10^{6}$ & $b$ \\
\hline & $\pm 3.2 \times 10^{6}$ & & $\pm 9.9 \times 10^{8}$ & & $\pm 1.0 \times 10^{6}$ & & $\pm 1.0 \times 10^{6}$ & \\
\hline
\end{tabular}

Values represent mean \pm standard deviation obtained from independent triplicates. Different letters indicate significant differences between lyoprotectants (Tukey's Honest Significant Difference test, $p<0.05$ )

obtained with the lyoprotectant containing micellar casein was not significantly different between 0,5 month and 1 month. At 3 months and 9 months, the loss of cultivability remained low for the lyoprotectant containing micellar casein ( $0.4 \mathrm{log}$ reduction) (Fig. 2). With the lyoprotectant containing only sucrose and the lyoprotectants containing whey and inulin, the loss of cultivability at 9 months storage was between 3 to $4 \log$ (Fig. 2). Moreover, at 9 months, cultivable bacteria obtained with the lyoprotectant containing micellar casein was significantly higher than cultivable bacteria obtained with the lyoprotectant containing only sucrose and the two others lyoprotectants $(p<0.05$, ANOVA) (Table 1$)$.

\section{Water activity measurements during long-term storage}

Throughout storage, sucrose $\mathrm{a}_{\mathrm{w}}$ values range from 0.247 to 0.291. Concerning $\mathrm{a}_{\mathrm{w}}$ values after freeze-drying (at 0 month), there were differences between the four lyoprotectants. Indeed, for sucrose, sucrose + whey and sucrose + inulin, $a_{w}$ were in the range 0.229 and 0.279 whereas $\mathrm{a}_{\mathrm{w}}$ was much lower for sucrose + micellar casein and equal to 0,053. A slight increase in $a_{w}$ values was observed for all the others lyoprotectants mainly due to water sorption during the $\mathrm{a}_{\mathrm{w}}$ measurements. Therefore, to remove the effect of $\mathrm{RH}$ variations of the osmometer room between the different storage times, the results were expressed through $a_{w}$ differences. Differences between $\mathrm{a}_{\mathrm{w}}$ of the lyoprotectant containing only sucrose and $\mathrm{a}_{\mathrm{w}}$ of lyoprotectants containing micellar casein, whey or inulin are presented in Fig. 3.

Differences between $\mathrm{a}_{\mathrm{w}}$ of the lyoprotectant containing only sucrose and $a_{w}$ of lyoprotectants containing whey or inulin were close to 0 throughout storage as shown by the linear regression lines. Consequently, $a_{w}$ values were almost stable during storage for these lyoprotectants.

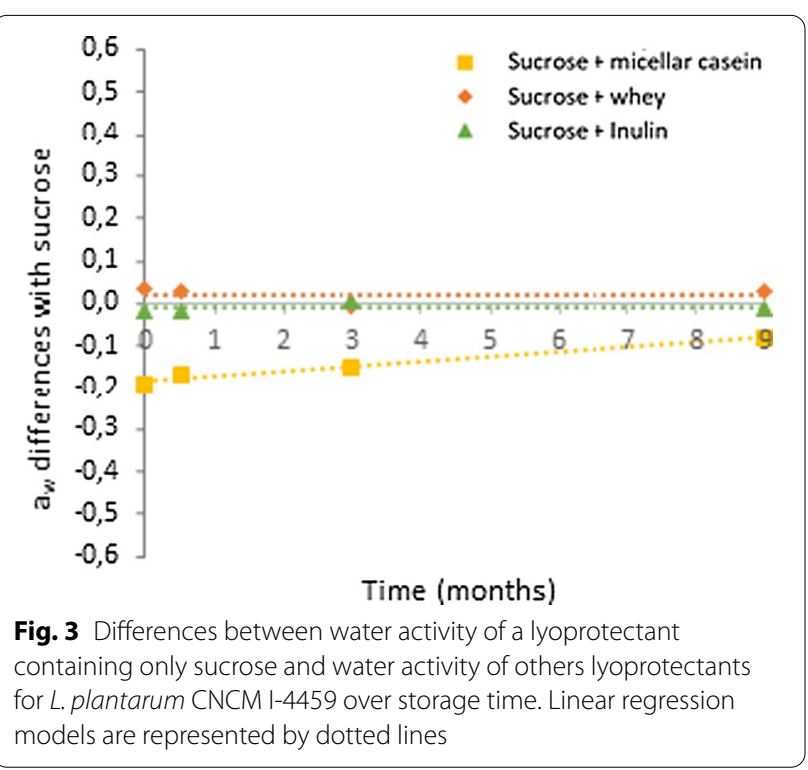

Therefore, the sealing of the samples was effective to limit $\mathrm{a}_{\mathrm{w}}$ variations during storage. Regarding the lyoprotectant containing micellar casein, although a slight increase was observed, $\mathrm{a}_{\mathrm{w}}$ values can also be considered constant over time. Moreover, for the lyoprotectant containing micellar casein, $\mathrm{a}_{\mathrm{w}}$ values (mean $\mathrm{a}_{\mathrm{w}}$ value: $0.13 \pm 0.05$ ) were significantly lower $(p<0.05$, ANOVA) than for the others lyoprotectants. Indeed, means $\mathrm{a}_{\mathrm{w}}$ values with sucrose, sucrose + whey and sucrose + inulin were $0.26 \pm 0.02$, $0.29 \pm 0.03$ and $0.26 \pm 0.02$, respectively.

\section{Discussion}

In this study, sucrose was an effective lyoprotectant allowing to preserve bacterial viability during a freezedrying process, which is consistent with previous reports 
found in literature $[20,45,46]$. Non-reducing disaccharides are effective lyoprotectants for bacterial freezedrying [20], including lactic acid bacteria freeze-drying $[45,46]$. The main reason of this protection is the water exit from the cell provoked by this disaccharides addition which affords a good resistance to freezing preventing from membrane vesiculation [7]. Moreover several studies have also demonstrated that sucrose can form an amorphous glass and hydrogen bonds with membrane proteins thus preventing cell damage from freeze-drying and subsequent storage [21, 47]. In our work the association of micellar casein, whey or inulin to sucrose had no significant effect on bacterial survival to freeze-drying. However, because of survival rates with sucrose were already close to $100 \%$, the effect of the addition of micellar casein, whey or inulin to sucrose on survival rates to freeze-drying of the strains can hardly be seen.

The results of this study also show that there is a significant influence of the lyoprotectant on $L$. plantarum CNCM I-4459 long-term storage survival. Contrary to what has been expected, the addition of whey or inulin to a sucrose solution did not increase the survival of this strain to long-term storage. However, the lyoprotectant containing micellar casein was significantly better for stabilizing the cultivable bacterial biomass during long term storage. Despite an initial mortality during the first three months of storage, the number of cultivable bacteria was then stable up to 9 months of storage resulting in $0.4 \log$ reduction. The mortality observed during the first three months of storage can be explained by the fact that the cells which have been damaged by freeze-drying, also undergo damage throughout storage (lipid oxidation, protein aggregation). Subsequently, freeze-dried cultivable bacterial biomass with sucrose + micellar casein remained stable if these cells had not been previously damaged by freeze-drying. A 1-log reduction achieved after 12 months of storage has been identified as economically viable [14]. Therefore, the lyoprotectant containing micellar casein is an effective and economically acceptable lyoprotectant for stabilizing bacterial biomass during freeze-drying and long-term storage.

Our results indicate that $L$. plantarum CNCM I-4459 storage survival depends on the $a_{w}$ after freeze-drying and its maintenance during storage. Hence, there was a clear link between the $a_{w}$ of the product and long-term storage survival, since the lower the $a_{w}$, the higher the bacterial survival to storage. The difference in $a_{w}$ after freeze-drying between the lyoprotectants with micellar casein and the other lyoprotectants can be explained through the sorption isotherms of these components presented in Fig. 4.

Indeed, sorption isotherm of micellar casein is very different from sorption isotherms of sucrose, whey

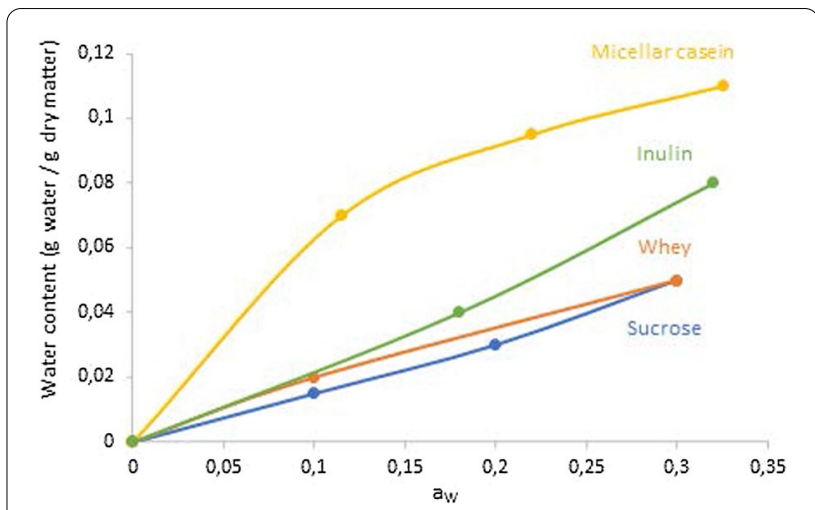

Fig. 4 Sorption isotherms of sucrose at $25^{\circ} \mathrm{C}$ (from [38]), of freeze-dried micellar casein at $27^{\circ} \mathrm{C}$ (from |35]), of whey protein concentrate (from [37]) and of inulin at $23^{\circ} \mathrm{C}$ (from [43])

or inulin [35-38, 42, 43]. Considering that the water content of both samples was close after freeze-drying (around $0.04 \mathrm{~g}$ water/g dry matter as previously obtained in our laboratory (data not shown)), then the corresponding $\mathrm{a}_{\mathrm{w}}$ values obtained from these isotherms in Fig. 4 coincide with the $\mathrm{a}_{\mathrm{w}}$ values measured after freeze-drying of the lyoprotectants. The difference between $a_{w}$ values of the lyoprotectant containing only sucrose and the lyoprotectant containing micellar casein is very high after freeze-drying for the same water content, which had a significant impact during storage and in particular in the acceleration of chemical degradation. Indeed, below the $\mathrm{T}_{\mathrm{g}}$, chemical degradations reactions such as Maillard reaction, proteins aggregations, deamidation and lipid oxidation of membrane fatty acid increase with $a_{w}[48,49]$. A few studies have also shown higher bacterial inactivation with higher $\mathrm{a}_{\mathrm{w}}$ during long-term storage and, have linked an increase of previously mentioned chemical reactions to bacterial death $[25,27,32]$. Therefore, a lower $\mathrm{a}_{\mathrm{w}}$ during storage must have limited biological reactions, thus increasing bacterial stability during storage.

To understand the particular sorption properties of micellar casein, we examined properties of caseinbased dairy powders. Casein-based dairy powders are currently used in food industry in cheese and yogurt manufacturing or in nutritional preparations due to their high protein content [50]. Caseins powders are generally dried by spray drying and the removal of water leads to the formation of aggregates of interlinked casein micelles. An increase of interactions between and within micellar casein was also noticed during storage of milk protein concentrate powders [51]. Moreover, the formation of a crust on the surface of micellar casein during storage, composed of layers of fused caseins, has been observed [52]. Therefore, 
micellar casein structure and the layer of fused caseins on the micelles surface could explain the particular sorption properties of this protein.

Our study demonstrated that bacterial survival to longterm storage depended on the high bound water content of components used as lyoprotectants. Therefore, for lactic acid bacteria strains survival to freeze-drying and to long-term storage, a lyoprotectant containing sucrose (for freezing protection and high $\mathrm{T}_{\mathrm{g}}$ ) and micellar casein (for high bound water content and high $\mathrm{T}_{\mathrm{g}}$ ) could interestingly be chosen.

\section{Conclusion}

The results of this study demonstrate the importance of the choice of the lyoprotectant for bacterial survival to long-term storage. For the same water content as for sucrose, whey and inulin, a significant lower water activity was obtained with the lyoprotectant containing micellar casein during storage. Therefore, with the lyoprotectant containing micellar casein, a higher bacterial viability to long-term storage was found. The higher bound water content of micellar casein could have resulted in less water available for chemical degradation reactions, responsible for bacterial damages during longterm storage. Therefore, the addition of micellar casein (for long term storage protection) to a sucrose solution (for freezing protection) can protect a lactic acid bacteria strain from freeze-drying stresses and from long-term storage degradation. Use of a lyoprotectant mixture with a high bound water content is thus a promising strategy for the food industry to improve lactic acid bacteria survival to long-term storage.

\section{Materials and methods}

\section{Bacterial strains and stock solutions}

Lactiplantibacillus plantarum CNCM I-4459 was provided by Novanat (Shanghai NOVANAT Co., China) and Lacticaseibacillus casei DSM 27537 and Lacticaseibacillus rhamnosus DSM 16605 strains were provided by Probiotical (PROBIOTICAL S.p.A, Italy). The three strains were cultured in MRS broth medium (Lactobacillus Broth acc. to De Man, Rogosa and Sharpe, SigmaAldrich) (pH $6.2 \pm 0.2$ at $25^{\circ} \mathrm{C}$ ) at $37^{\circ} \mathrm{C}$ for $24 \mathrm{~h}$. The MRS medium was prepared according to the manufacturer's instructions and sterilized at $121^{\circ} \mathrm{C}$ for 20 min after the addition of $0.1 \%(\mathrm{v} / \mathrm{v})$ Tween 80 (Sigma-Aldrich). Cultures were then diluted to $20 \%$ in sterile glycerol (Honeywell, USA) (v/v), then aliquoted in $1 \mathrm{~mL}$ cryotubes and stored at $-80{ }^{\circ} \mathrm{C}$ until further use.

\section{Culture conditions}

Bacteria were streaked out $(100 \mu \mathrm{l})$ on MRS agar and incubated $24 \mathrm{~h}$ at $37^{\circ} \mathrm{C}$. Following incubation, one colony was inoculated in $10 \mathrm{~mL}$ of MRS broth (pre-cultures). Finally, after $24 \mathrm{~h}$ at $37^{\circ} \mathrm{C}$, fresh MRS $(10 \mathrm{~mL})$ was inoculated at $1 \%(\mathrm{v} / \mathrm{v})$ with pre-cultures and incubated at $37^{\circ} \mathrm{C}$.

\section{Freeze-drying}

Four different formulas of lyoprotectants were used: sucrose, sucrose + whey, sucrose + micellar casein and sucrose + inulin. These lyoprotectants were composed of $5 \%(\mathrm{~m} / \mathrm{v})$ sucrose (Sigma-Aldrich) in PBS (Phosphate Buffered Saline, Sigma-Aldrich) and of 5\% whey protein isolate (degree of hydrolysis $=25 \%$, 25S, Ingrediat, France) or $5 \%$ micellar casein (87B Fluid, Ingredia, France) or 5\% inulin DP10 (Fibruline ${ }^{\circledR}$ Instant, Cosucra). Bacterial cells were centrifuged $(4,000 \mathrm{~g}-10 \mathrm{~min}$, Eppendorf $5810 \mathrm{R}$ ) and pellets resuspended (10 times concentrated) in the different lyoprotectants. One milliliter of each mixture was poured into vials (amber glass vials of $5 \mathrm{~mL}$ ) and frozen at $-80{ }^{\circ} \mathrm{C}$ (at a rate of $-2{ }^{\circ} \mathrm{C} / \mathrm{min}$ ) before being freeze-dried for $24 \mathrm{~h}$ (FreeZone 18-Liter Console Freeze Dry System with Stoppering Tray Dryer, Purge Valve and PTFE-Coated Collector, Labconco, Kansas City, USA). Sublimation was carried out by maintaining the samples for $2 \mathrm{~h}$ at $-40{ }^{\circ} \mathrm{C}$ (condenser temperature $=-55{ }^{\circ} \mathrm{C}$ and chamber pressure $=10 \mathrm{~Pa}$ ), then increasing the chamber temperature to $0{ }^{\circ} \mathrm{C}$ at a speed of $0.04{ }^{\circ} \mathrm{C} / \mathrm{min}$. After $17 \mathrm{~h}$, the chamber temperature was increased to $25{ }^{\circ} \mathrm{C}$ at a heating rate of $0.08{ }^{\circ} \mathrm{C} /$ min to carry out the secondary desorption.

\section{Long-term storage}

Due to the large number of samples (160 for one strain) needed to measure the cultivable bacteria and the $a_{w}$ throughout long-term storage, the influence of the four lyoprotectants on bacterial survival to long-term storage has only been studied for the strain L. plantarum CNCM I-4459. Moreover the strain L. plantarum CNCM I-4459 was selected for the long-term storage study because the freeze-drying survival and the cultivable biomass after freeze-drying (at 0 month) were not significantly different between the four lyoprotectants. After freeze-drying, vials were sealed with butyl rubble stoppers and aluminum screw caps under vacuum $(10 \mathrm{~Pa})$ which afforded to keep a constant $a_{w}$ value during storage. Samples were then stored for 9 months at $25{ }^{\circ} \mathrm{C}$ in the dark. Before water activity measurements or bacterial enumeration at each storage time, the maintenance of the samples under vacuum was checked.

\section{Water activity measurements}

Water activity of the lyophilizates was measured at $25^{\circ} \mathrm{C}$ using an Aqualab CX-2 Osmometer (Decagon Devices, Pullman, WA, USA) after freeze-drying and at each storage time (15 days, 3 months and 9 months). At 1 month 
of storage, $a_{w}$ has not been measured. The freeze-dried samples contained in five vials were regrouped for one $a_{w}$ measurement, corresponding to one storage time. To remove the effect of $\mathrm{RH}$ variations of the osmometer room between the different storage times, the results were expressed through $\mathrm{a}_{\mathrm{w}}$ differences, i.e. for each storage time the difference between $a_{w}$ of sucrose and $a_{w}$ of others lyoprotectants were calculated.

\section{Bacterial survival to freeze-drying and long-term storage} Cultivable bacteria were enumerated using the method of Colony Forming Units (CFU/mL and CFU/g of lyophilizate) after freeze-drying and at each storage time (15 days, 1 month, 3 months and 9 months). Rehydration was performed with $1 \mathrm{~mL}$ of MRS broth at $37^{\circ} \mathrm{C}$ to enumerate viable cells. Bacterial survival rate to the freezedrying process (\%) was expressed as the ratio between the cultivable bacteria after freeze-drying $(\mathrm{CFU} / \mathrm{mL})$ and before freeze-drying $(\mathrm{CFU} / \mathrm{mL})$. Due to the large variations between the cultivable bacteria during storage, the loss of cultivability during long-term storage was expressed in $\log _{10}\left(\mathrm{~N} / \mathrm{N}_{0}\right)$, where $\mathrm{N}$ corresponds to the cultivable bacteria at the time of storage (CFU/g of lyophilizate) and $\mathrm{N}_{0}$ corresponds to the cultivable bacteria at 0 month (CFU/g of lyophilizate).

\section{Statistical analysis}

An analysis of variance (ANOVA) was used to investigate effects of the four lyoprotectants on freeze-drying and storage survival $(p<0.05)$. For each lyoprotectant, an ANOVA was also performed to compare cultivable bacteria and survival rates between each storage time. When significant differences were observed, Tukey's Honest Significant Difference test was performed. Significant differences between the bacterial concentrations and survival rates were shown with different letters in the Figures. One-sample t-test was used to compare mean values with specified values $(p<0.05)$. All experiments were carried out in completely independent triplicates $(n=3)$, except for $\mathrm{a}_{\mathrm{w}}$ measurements. The R Software v.3.3.2 ( $\mathrm{R}$ Development Core Team, 2008) was used to statistically analyze data.

\section{Abbreviations \\ ANOVA: Analysis of variance; $\mathrm{a}_{\mathrm{w}}$ : Water activity; CFU: Colony forming units; LAB: Lactic Acid Bacteria; MRS: Lactobacillus Broth acc. to De Man, Rogosa and Sharpe, Sigma-Aldrich; $\mathrm{RH}$ : Relative Humidity; $T_{\mathrm{g}}$ : Glass transition temperature of the protectant.}

\section{Acknowledgements}

We would like to thank the Fonds Européen de Développement Régional (FEDER) which participated in the financing of the Freeze Dryer. We would also like to thank the Institute MICALIS (INRAe in Jouy-en-Josas) for providing the bacterial strains.
Authors' contributions

$A B, S D, L B, S L$ and $P G$ designed the research. $A B$ and $A J$ performed the experiments. $A B, S D$ and $P G$ analyzed the data. SD, LB and PG helped in writing the manuscript and revised the manuscript. $A B$ wrote the manuscript. P-YM, LB, SL and PG supervised the work. PG edited the manuscript. All authors read and approved the final manuscript.

\section{Funding}

This work was supported by the University of Burgundy, the company Indigo Therapeutics and the National Agency for Research ANRT (CIFRE N ${ }^{\circ}$ 2016/0787). Personal salaries of A.B and A.J were funded by the ANRT. Personal salaries of S.D, L.B and P.G were funded by the University of Burgundy. Personal salaries of S.L and P-Y.M were funded by Indigo Therapeutics. All consumables used in this study were funded by the ANRT.

Availability of data and materials

The datasets used and/or analyzed during the current study are available from the corresponding author on reasonable request.

\section{Declarations}

Ethics approval and consent to participate

Not applicable.

Consent for publication

Not applicable.

\section{Competing interests}

The authors declare that they have no competing interests.

\section{Author details}

${ }^{1}$ UMR Procédés Alimentaires et Microbiologiques, University Bourgogne Franche-Comté, AgroSup Dijon, PAM UMR A 02.102, 21000 Dijon, France. ${ }^{2}$ Indigo Therapeutics, 5 rue Salneuve, 75017 Paris, France.

Received: 31 May 2021 Accepted: 8 November 2021

Published online: 12 November 2021

\section{References}

1. Broeckx G, Vandenheuvel D, Claes IJJ, Lebeer S, Kiekens F. Drying techniques of probiotic bacteria as an important step towards the development of novel pharmabiotics. Int J Pharm. 2016;505:303-18. https://doi. org/10.1016/j.ijpharm.2016.04.002.

2. Vesterlund S, Salminen K, Salminen S. Water activity in dry foods containing live probiotic bacteria should be carefully considered: a case study with Lactobacillus rhamnosus GG in flaxseed. Int J Food Microbiol. 2012;157:319-21. https://doi.org/10.1016/j.ijfoodmicro.2012.05.016.

3. De Marañon IM, Marechal PA, Gervais P. Passive response of Saccharomyces cerevisiae to osmotic shifts: cell volume variations depending on the physiological. Biochem Biophys Res Commun. 1996;227:519-23. https:// doi.org/10.1006/bbrc.1996.1539.

4. Mazur P. The role of intracellular freezing in the death of cells cooled at supraoptimal rates. Cryobiology. 1977;14:251-72. https://doi.org/10. 1016/0011-2240(77)90175-4.

5. Dumont F, Marechal PA, Gervais P. Influence of cooling rate on Saccharomyces cerevisiae destruction during freezing: unexpected viability at ultra-rapid cooling rates. Cryobiology. 2003;46(1):33-42.

6. Steponkus PL, Lynch DV. Freeze/thaw-induced destabilization of the plasma membrane and the effects of cold acclimation. J Bioenerg Biomembr. 1989;21:21-41. https://doi.org/10.1007/BF00762210.

7. Schwarz H, Koch AL. Phase and electron microscopic observations of osmotically induced wrinkling and the role of endocytotic vesicles in the plasmolysis of the Gram-negative cell wall. Microbiology. 1995;141:316170. https://doi.org/10.1099/13500872-141-12-3161.

8. Mille Y, Beney L, Gervais P. Magnitude and kinetics of rehydration influence the viability of dehydrated E. coli K-12. Biotechnol Bioeng. 2003;83:578-82. https://doi.org/10.1002/bit.10706. 
9. Mazur P. Physical-chemical basis of injury from intracellular freezing in yeast. Cell Inj Resist Freez Org Proc. 1967;2:171-89.

10. Fowler A, Toner M. Cryo-injury and biopreservation. Ann N Y Acad Sci. 2006;1066:119-35. https://doi.org/10.1196/annals.1363.010.

11. Morgan CA, Herman N, White PA, Vesey G. Preservation of micro-organisms by drying; a review. J Microbiol Methods. 2006;66:183-93. https:// doi.org/10.1016/j.mimet.2006.02.017.

12. Pikal MJ, Shah S. The collapse temperature in freeze drying: Dependence on measurement methodology and rate of water removal from the glassy phase. Int J Pharm. 1990;62:165-86. https://doi.org/10.1016/03785173(90)90231-R

13. Wang W. Lyophilization and development of solid protein pharmaceuticals. Int J Pharm. 2000;203:1-60. https://doi.org/10.1016/S0378-5173(00) 00423-3.

14. Makinen K, Berger B, Bel-Rhlid R, Ananta E. Science and technology for the mastership of probiotic applications in food products. J Biotechnol. 2012;162:356-65. https://doi.org/10.1016/j.jbiotec.2012.07.006.

15. Haseley $\mathrm{P}$, Oetjen G-W. Foundations and process engineering. In: FreezeDrying 3e. Wiley-VCH Verlag GmbH \& Co. KGaA; 2017. p. 1-176.

16. Hatley RHM, Blair JA. Stabilisation and delivery of labile materials by amorphous carbohydrates and their derivatives. J Mol Catal B Enzym. 1999:7:11-9.

17. Angell CA. Formation of glasses from liquids and biopolymers. Science. 1995:267:1924-35. https://doi.org/10.1126/science.267.5206.1924.

18. Hagen SJ, Hofrichter J, Eaton WA. Protein reaction kinetics in a roomtemperature glass. Science. 1995;269:959-62. https://doi.org/10.1126/ science.7638618.

19. Marín A, Atarés L, Cháfer M, Chiralt A. Stability of biocontrol products carrying Candida sake CPA-1 in starch derivatives as a function of water activity. Biocontrol Sci Technol. 2017;27:268-87. https://doi.org/10.1080/ 09583157.2017 .1279587$.

20. Leslie SB, Israeli E, Lighthart B, Crowe JH, Crowe LM. Trehalose and sucrose protect both membranes and proteins in intact bacteria during drying. Appl Environ Microbiol. 1995;61:3592-7.

21. Passot S, Cenard S, Douania I, Tréléa IC, Fonseca F. Critical water activity and amorphous state for optimal preservation of lyophilised lactic acid bacteria. Food Chem. 2012;132:1699-705. https://doi.org/10.1016/j.foodc hem.2011.06.012.

22. Carpenter JF, Crowe JH. Modes of stabilization of a protein by organic solutes during desiccation. Cryobiology. 1988;25:459-70.

23. Carpenter JF, Crowe JH. An infrared spectroscopic study of the interactions of carbohydrates with dried proteins. Biochemistry. 1989;28:391622. https://doi.org/10.1021/bi00435a044.

24. Higl B, Kurtmann L, Carlsen CU, Ratjen J, Först P, Skibsted LH, et al. Impact of water activity, temperature, and physical state on the storage stability of Lactobacillus paracasei ssp. paracasei freeze-dried in a lactose matrix. Biotechnol Prog. 2007;23:794-800. https://doi.org/10.1021/bp070089d.

25. Kurtmann L, Carlsen CU, Skibsted LH, Risbo J. Water activity-temperature state diagrams of freeze-dried Lactobacillus acidophilus (La-5): Influence of physical state on bacterial survival during storage. Biotechnol Prog. 2009:25:265-70. https://doi.org/10.1002/btpr.96.

26. Heidebach T, Först P, Kulozik U. Influence of casein-based microencapsulation on freeze-drying and storage of probiotic cells. J Food Eng. 2010;98:309-16. https://doi.org/10.1016/j.jfoodeng.2010.01.003.

27. Castro HP, Teixeira PM, Kirby R. Storage of lyophilized cultures of Lactobacillus bulgaricus under different relative humidities and atmospheres. Appl Microbiol Biotechnol. 1995;44:172-6.

28. Pehkonen KS, Roos YH, Miao S, Ross RP, Stanton C. State transitions and physicochemical aspects of cryoprotection and stabilization in freeze-drying of Lactobacillus rhamnosus GG (LGG). J Appl Microbiol. 2008;104:1732-43. https://doi.org/10.1111/j.1365-2672.2007.03719.x.

29. Ying DY, Phoon MC, Sanguansri L, Weerakkody R, Burgar I, Augustin MA. Microencapsulated Lactobacillus rhamnosus GG powders: relationship of powder physical properties to probiotic survival during storage. J Food Sci. 2011;75:E588-95. https://doi.org/10.1111/j.1750-3841.2010.01838.x.

30. Miao S, Mills S, Stanton C, Fitzgerald GF, Roos Y, Ross RP. Effect of disaccharides on survival during storage of freeze dried probiotics. Dairy Sci Technol. 2008;88:19-30. https://doi.org/10.1051/dst:2007003.

31. Zhu SC, Ying DY, Sanguansri L, Tang JW, Augustin MA. Both stereoisomers of glucose enhance the survival rate of microencapsulated
Lactobacillus rhamnosus GG during storage in the dry state. J Food Eng. 2013;116:809-13. https://doi.org/10.1016/j.jfoodeng.2013.01.028.

32. Agudelo J, Cano A, González-Martínez C, Chiralt A. Disaccharide incorporation to improve survival during storage of spray dried LactobacilIus rhamnosus in whey protein-maltodextrin carriers. J Funct Foods. 2017;37:416-23. https://doi.org/10.1016/j.ff.2017.08.014.

33. Zayed G, Roos YH. Influence of trehalose and moisture content on survival of Lactobacillus salivarius subjected to freeze-drying and storage. Process Biochem. 2004;39:1081-6. https://doi.org/10.1016/S00329592(03)00222-X

34. Carvalho AS, Silva J, Ho P, Teixeira P, Malcata FX, Gibbs P. Relevant factors for the preparation of freeze-dried lactic acid bacteria. Int Dairy J. 2004;14:835-47. https://doi.org/10.1016/j.idairyj.2004.02.001.

35. Diamante LM. Casein drying. Massey University; 1991.

36. Berlin E, Kliman PG, Anderson BA, Pallansch MJ. Water binding in whey protein concentrates. J Dairy Sci. 1973;56:984-7.

37. Sawhney IK, Sarkar BC, Patil GR, Sharma HK. Moisture sorption isotherms and thermodynamic properties of whey protein concentrate powder from buffalo skim milk. J Food Process Preserv. 2014;38:1787-98. https:// doi.org/10.1111/jfpp.12148.

38. Yu X, Kappes SM, Bello-Perez LA, Schmidt SJ. Investigating the moisture sorption behavior of amorphous sucrose using a dynamic humidity generating instrument. J Food Sci. 2007;73:E25-35. https://doi.org/10.1111/j. 1750-3841.2007.00596.x.

39. Ronkart SN, Blecker CS, Deroanne C, Paquot M. Phénomène de la transition vitreuse appliquée aux glucides alimentaires amorphes à l'état de poudre. Biotechnol Agron Soc Environ. 2009;13. https://popups.uliege.be: 443/1780-4507/index.php?id=3686. Accessed 26 June 2020.

40. Schwab C, Vogel R, Ganzle MG. Influence of oligosaccharides on the viability and membrane properties of Lactobacillus reuteri TMW1.106 during freeze-drying. Cryobiology. 2007:55:108-14. https://doi.org/10.1016/j. cryobiol.2007.06.004.

41. Romano N, Mobili P, Zuñiga-Hansen M-E, Gómez-Zavaglia A. Physicochemical and structural properties of crystalline inulin explain the stability of Lactobacillus plantarum during spray-drying and storage. Food Res Int. 2018;113:167-74. https://doi.org/10.1016/J.FOODRES.2018.07.007.

42. Ronkart S, Blecker C, Fougnies C, Van Herck JC, Wouters J, Paquot M. Determination of physical changes of inulin related to sorption isotherms: an X-ray diffraction, modulated differential scanning calorimetry and environmental scanning electron microscopy study. Carbohydr Polym. 2006;63:210-7.

43. Schaller-Povolny LA, Smith DE, Labuza TP. Effect of water content and molecular weight on the moisture isotherms and glass transition properties of inulin. Int J Food Prop. 2000;3:173-92. https://doi.org/10.1080/ 10942910009524626.

44. Romano N, Schebor C, Mobili P, Gómez-Zavaglia A. Role of mono- and oligosaccharides from FOS as stabilizing agents during freeze-drying and storage of Lactobacillus delbrueckii subsp. bulgaricus. Food Res Int. 2016;90:251-8. https://doi.org/10.1016/j.foodres.2016.11.003.

45. De Giulio B, Orlando P, Barba G, Coppola R, De Rosa M, Sada A, et al. Use of alginate and cryo-protective sugars to improve the viability of lactic acid bacteria after freezing and freeze-drying. World J Microbiol Biotechnol. 2005;21:739-46.

46. Schwab C, Walter J, Tannock GW, Vogel RF, Ganzle MG. Sucrose utilization and impact of sucrose on glycosyltransferase expression in Lactobacillus reuteri. Syst Appl Microbiol. 2007;30:433-43. https://doi.org/10.1016/j. syapm.2007.03.007.

47. Crowe JH, Crowe LM, Carpenter JF, Aurell WC. Stabilization of dry phospholipid bilayers and proteins by sugars. Biochem J. 1987;242:1-10. https://doi.org/10.1042/bj2420001.

48. Mensink MA, Frijlink HW, van der Voort MK, Hinrichs WLJ. How sugars protect proteins in the solid state and during drying (review): mechanisms of stabilization in relation to stress conditions. Eur J Pharm Biopharm. 2017:114:288-95

49. Lai MC, Topp EM. Solid-state chemical stability of proteins and peptides. J Pharm Sci. 1999:88:489-500.

50. Carr A, Golding M. Functional milk proteins production and utilization: Casein-based ingredients. In: Advanced dairy chemistry: volume 1B: proteins: applied aspects: 4th edition. New York: Springer; 2016. p. 35-66. doi:https://doi.org/10.1007/978-1-4939-2800-2_2. 
51. Mimouni A, Deeth HC, Whittaker AK, Gidley MJ, Bhandari BR. Investigation of the microstructure of milk protein concentrate powders during rehydration: alterations during storage. J Dairy Sci. 2010;93:463-72. https:// doi.org/10.3168/jds.2009-2369.

52. Fyfe KN, Kravchuk O, Le T, Deeth HC, Nguyen AV, Bhandari B. Storage induced changes to high protein powders: influence on surface properties and solubility. J Sci Food Agric. 2011;91:2566-75. https://doi.org/10. 1002/jsfa.4461.

\section{Publisher's Note}

Springer Nature remains neutral with regard to jurisdictional claims in published maps and institutional affiliations.
Ready to submit your research? Choose BMC and benefit from:

- fast, convenient online submission

- thorough peer review by experienced researchers in your field

- rapid publication on acceptance

- support for research data, including large and complex data types

- gold Open Access which fosters wider collaboration and increased citations

- maximum visibility for your research: over $100 \mathrm{M}$ website views per year

At BMC, research is always in progress.

Learn more biomedcentral.com/submissions 